\title{
Energy Efficiency and Power Quality in Low Income Consumer Units
}

\author{
Arnulfo Barroso de Vasconcellos', Dr.; Jéssica Romeiro de Carvalho', Acad.; Manoel Alexandre de Oliveira', \\ Acad. ; Douglas Pinto Sampaio Gomes', Acad.; Teresa Irene Ribeiro de Carvalho Malheiro², PhD.
}

\begin{abstract}
${ }^{-}$Federal University of Mato Grosso - UFMT. Av. Fernando Correa da Costa, S/N, Coxipó, Cuiabá-MT. Phone: +55-65-3615-8784, e-mail: A. B. de Vasconcellos, arnulfo@ufmt.br; M. A. de Oliveira, manoel_oliveira@@hotmail.com; D.P.S. Gomes, douglas.uf@gmail.com; J.R.de Carvalho, jessica.romeiro@hotmail.com.
\end{abstract}

\author{
${ }^{2}$ Federal Institute of Education, Science and Technology of Mato Grosso - IFMT \\ Phone: +55-65-3316-5554, e-mail: T. I. R. C. Malheiro, malheiro.teresa@gmail.com
}

\begin{abstract}
The purpose of this paper is to analyze the exchange of incandescent light bulbs by fluorescent ones and old coolers by compact coolers class A Procel Stamped in Consumer Units with low income, who brings besides the increased energy efficiency, positive impact on consumers lives. However, when observing the effects of fluorescent lighting on electric power quality systems where they are applied, there is the appearance of unwanted harmonic distortion on the network. This paper examines the process of replacing the proposed system and verifies the impact on reducing energy consumption and power quality.
\end{abstract}

Key words - Electrical Efficiency, Power Quality, Reduced Active Power Consumption, Household Refrigerators, Lighting System, Retrofit.

\section{INTRODUCTION}

The project "Luz em Conta" (Cheap Power), developed by REDE/CEMAT since 2004, performs the exchange of incandescent light bulbs by compact fluorescent lamps (CFLs) $20 \mathrm{~W}$ and old refrigerators by 300L Procel Stamped coolers of underprivileged families.

Those selected to be beneficiaries of the program receive a new refrigerator and deliver the old one to REDE / CEMAT, which gives orders for environmentally appropriate disposal of the appliance.

As a result of this action, the families are benefited with a new and efficiently cooler with saves energy, while old machines had high electricity consumption. The appliance replacement is free and aims to contribute to reducing the energy consumption of these Consumer Units, impacting on reducing the load curve at the peak of the electric system.

In addition to reducing electricity costs by replacing of equipment in poor functioning by electrical appliances more efficiently, a key goal of the program is to decrease the user's electric bill cost, so that this consumer be able to remain compliant.

Given the large increase of nonlinear loads in distribution network with the entry of CFLs, causing "pollution" of the power grid with harmonics due to the fact that they absorb the current does not have the same waveform voltage that feeds them, may cause several drawbacks like burning engines or inadequate functioning of sensitive electronic equipment.

Nowadays, in addition to the energy requirement of high quality, there is now also increasing stringency to the loads connected to the electrical systems and how these impact negatively, once the presence of harmonics in the power system (as is domain area) results in increased losses related to the transmission and distribution of electricity, creating problems of interference in communication systems and malfunctioning piece of equipment connected to the network.

International standards for power quality, such as IEEE 519, IEC 61000 and EN 50160 [1] - [2] - [3] - [4] - [5] - [6] set limits for levels of distortion harmonic voltage with which the electrical systems can operate properly, and so new equipment does not go beyond certain values in the current injection.

Therefore, it becomes clear the need to solve problems associated by waveform distortion, both for new equipment as for the already installed. In Brazil, the concern for power quality is a real issue, considering the commitment of regulators (ANEEL), utilities and consumers. ANEEL through distribution procedures (Prodist), published in December 2008 in its module 8 [7] deals with the quality of electric power with respect to product and service nationwide. [8]-[9]

From this perspective, the present work aims to study the electrical efficiency in replacement of bulbs and coolers and analysis of power quality in low-income consumer units in the state of Mato Grosso. 
The paper presents the results of electrical measurements performed focused on the environment and explores the issues related to the economy energy, demand reduction of active power at the peak and power quality.

\section{ENERGY EFFICIENCY}

\section{A. Consumer Profile and Equipment Used in Measuring}

Low income Consumer Units were assisted by the Project in suburbs of the cities Barra do Garças, Cáceres, Chapada dos Guimarães, Cuiabá, Guiratinga, Jangada, Juscimeira, Poconé, Rondonópolis, Santo Antônio do Leverger, Sinop, Tangará da Serra and Várzea Grande, in the state of Mato Grosso. Table I illustrates the load installed of the Lighting System (SI) and Refrigeration System (SR) before and after the replacement process.

TABLE I. LOAD OF LIGHTING SYSTEMS INSTALLED AND REFRIGERATION PROCESS BEFORE AND AFTER REPLACEMENT

\begin{tabular}{lcc|cc}
\hline & SI $_{\text {Before }}$ & SR $_{\text {Before }}$ & SI $_{\text {After }}$ & SR $_{\text {After }}$ \\
\hline Quantity (un.) & 5112 & 1300 & 5112 & 1300 \\
Average Power (W) & 100 & 112 & 22 & 94 \\
\hline
\end{tabular}

The equipment used in order to record the electrical values and subsequently verify the performance of energy efficiency projects was the energy analyzer MARH-21 Manufacturer (RMS) and the instrument used to measure the operating time of the lamp was the Hourmeter.

\section{B. Replacement Lighting and Cooling System of Consumer Units}

The Lighting system inside of Consumer Units (UC's) before implantation of the replacement process consisted of several sets of lighting. In this project were replaced basically incandescent $100 \mathrm{~W}$ lamps by 20W LFCs lamps.

Figure 1 illustrates the Average Total Active Power of a 100W incandescent and 20W fluorescent lamps with electronic ballast.

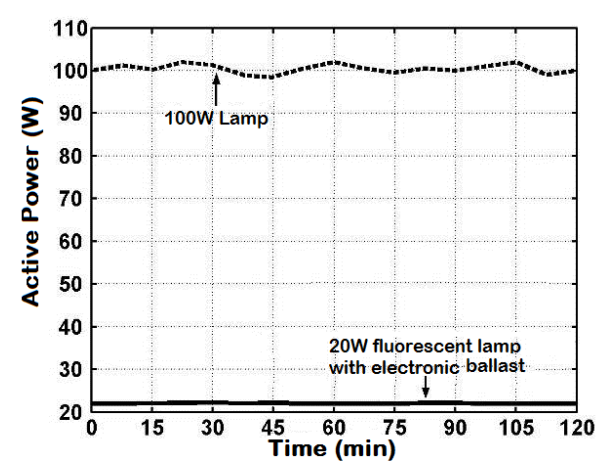

Fig. 1. Comparison of Total Active Power 100W incandescent lamp with a $20 \mathrm{~W}$ fluorescent lamp with electronic ballast.

The Cooling System in UC's, before deployment process electrical efficiency, consisted of old refrigerators in various capacities of which were replaced by refrigerators PROCEL stamped of 300L

Figure 2 illustrates the Average Total Active Power of an old refrigerator and a refrigerator Procel.

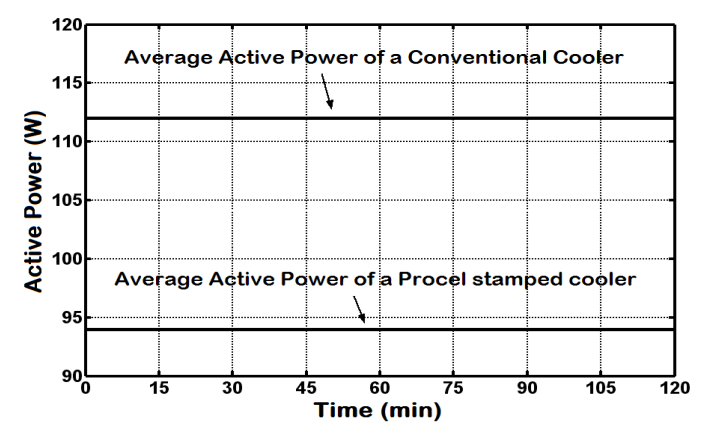

Fig. 2. Comparison of Active Power Coolers Conventional type (Low Rate) with the type PROCEL 300 L (High Rate).

The limits to determine the savings of electric energy and Demand of Active Power were identified by measurements on samples of around 80 bulbs before and after the replacement, and from 50 refrigerators, before and after the replacement process. The sample size was based on a sampling plan defined by NBR 5426, under level I.

\section{REDUCTION OF ANNUAL ELECTRICITY CON- SUMPTION AND DEMAND FOR ACTIVE POWER}

In Consumer Units there were several incandescent 100W bulbs, whose run time was obtained by measurements performed by the hour meter, as illustrated in Figure 3.

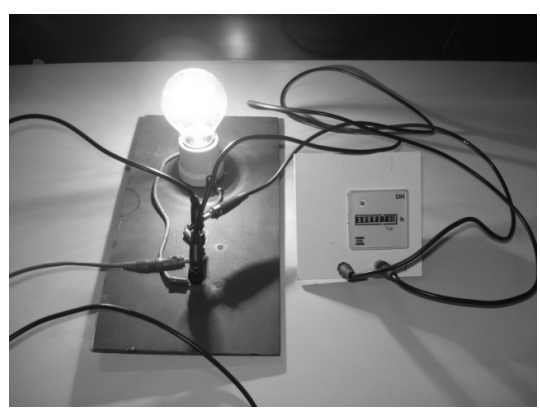

Fig. 3. Hour meter registering the operating time of the incandescent lamp.

The following are the calculations of Electricity Consumption and Demand Active Power, before and after replacement systems for lighting and refrigeration.

A. Reduction of annual consumption of Electricity and Active Power Demands for lighting and cooling systems

The total power (PT) installed in Consumer Units is given by (1) and electricity consumption (CA) by (2):

$$
\mathrm{PT}_{\mathrm{i}}=\mathrm{N} \times Y
$$


Where:

$\mathrm{PT}_{\mathrm{i}}=$ Total Installed Power System $i(\mathrm{KW})$;

$\mathrm{N}=$ Power measured for each set (W);

$\mathrm{Y}=\mathrm{N}^{\mathrm{o}}$ of lamps or sets of lamps.

$$
\mathrm{CA}_{\mathrm{i}}=\mathrm{PT}_{\mathrm{i}} \times \mathrm{T}
$$

Where:

$\mathrm{CA}_{\mathrm{i}}=$ Consumption of electric power system $i$ (KWh);

$\mathrm{PT}_{\mathrm{i}}=$ Total Installed Power System $i(\mathrm{KW})$;

$\mathrm{T}=$ hours of operation of each system (in hours in a year).

Table II shows the electricity consumption (kWh / year) per system, before and after the replacement process, considering that equipment work 30 days a month, twelve months a year.

TABLE II. ELECTRICAL ENERGY CONSUMPTION BY SYSTEM BEFORE AND AFTER THE REPLACEMENT

\begin{tabular}{lcc|cc}
\hline & SI $_{\text {Before }}$ & $\mathbf{S R}_{\text {Before }}$ & SI $_{\text {After }}$ & SR $_{\text {After }}$ \\
\hline Pti (kW) & 511,20 & 145,60 & 112,46 & 122,20 \\
CA (kWh/year & $736.128,00$ & $891.072,00$ & $161.942,40$ & $395.928,00$ \\
T (hours) & 04 & 17 & 04 & 09 \\
\hline
\end{tabular}

B. Calculation of Annual Consumption Reduction (RCA) of Electricity and Active Power Demand (RPT)

The calculation of the reduction in annual consumption of electricity was conducted through (3):

$$
\mathrm{RCA}_{\mathrm{i}}=\mathrm{CA}_{\text {Before }}-\mathrm{CA}_{\text {After }}
$$

Where:

$\mathrm{RCA}_{\mathrm{i}}$ is the reduction of energy consumption due to the replacement of the system $i$;

$\mathrm{CA}_{\text {Before }}$ is the electricity consumption before the replacement process;

$\mathrm{CA}_{\mathrm{After}}$ is the consumption of electricity after the replacement process.

The calculation of demand reduction of active power was accomplished through (4):

Where:

$$
\mathrm{RPT}_{\mathrm{i}}=\mathrm{PT}_{\text {Before }}-\mathrm{PT}_{\text {After }}
$$

$\mathrm{RPT}_{\mathrm{i}}$ is the reduction of active power demand due to the replacement system $i$;

$\mathrm{PT}_{\text {Before }}$ is the active power before the replacement process;

$\mathrm{PT}_{\mathrm{After}}$ is the active power after replacement process.

Table III presents the Reduction of Energy Consumption (kWh / year) and Active Power Demand Reduction (KW) per set due to the replacement process.

TABLE III. REDUCTION OF ELECTRICAL ENERGY ONSUMPTION AND DEMAND REDUCTION OF ACTIVE POWER

\begin{tabular}{lcc}
\hline & SI & SR \\
\hline RCA (kWh/year) & $574.185,6($ & $495.144,00$ \\
RPT (kW) & 398,74 & 23,40
\end{tabular}

C. Calculation of Total Annual Consumption Reduction in Electricity Demand

The calculation of the reduction of total electric power consumption (RCATotal) is conducted by the sum of reductions in energy consumption, resulting from the replacement of lighting and cooling, expressed in (5).

$$
\mathrm{RCA}_{\text {Total }}=\mathrm{RCA}_{\mathrm{SI}}+\mathrm{RCA}_{\mathrm{SR}}
$$

The calculation of demand reduction of total active power (RPTTotal) is performed by adding the power demand reductions resulting from the replacement of the active systems of lighting and cooling, expressed in (6).

$$
\mathrm{RPT}_{\text {Total }}=\mathrm{RPT}_{\mathrm{SI}}+\mathrm{RPT}_{\mathrm{SR}}
$$

Table IV presents the Reducing Total Annual Electricity Consumption and Demand Active Power, where we can see great potential for Energy Efficiency in Low-Income Consumer Units.

\section{TABLE IV. REDUCTION OF TOTAL CONSUMPTION OF} ELECTRICITY

AND DEMAND REDUCTION OF ACTIVE POWER

\begin{tabular}{lc}
\hline $\mathbf{R C A}_{\text {Total }}(\mathbf{k W h} / \mathbf{y e a r})$ & $1.069 .329,60$ \\
$\mathbf{R P T}_{\text {Total }}(\mathbf{k W})$ & 422,14 \\
\hline
\end{tabular}

D. Analysis of the electricity bill of a Consumer Unit after the replacement process

Figure 4 shows the historical electricity consumption of Consumer Unit number 10247675 assisted on this energy efficiency project design, where there were three $100 \mathrm{~W}$ incandescent lamps replaced by three CFLs of $20 \mathrm{~W}$ and an old refrigerator replaced by a refrigerator PROCEL stamped in the month of December 2009, and has already result in the months of January and February 2010 a significant reduction of energy consumption.

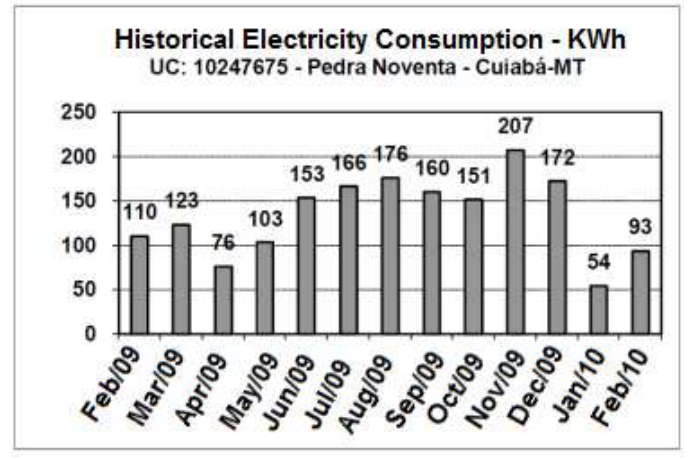

Fig. 4. Electricity Consumption of UC answered by Project of Energy Efficiency. 
This reduction in energy consumption was recorded on the invoice provided by the reduction of lighting systems and cooling electricity consumption after replacing incandescent bulbs by CFLs and old refrigerators and freezers with PROCEL respectively, with the implementation of Project Efficiency energy in Consumer Units.

\section{ANALYSIS OF ENERGY QUALITY}

\section{A. Conceptualization and classification of harmonics}

Voltage or current signals in the presence of harmonics present periodic behavior. These signals have, in addition to fundamental frequency, integer multiples of this frequency, so the waveform presents deformable in relation to a purely sinusoidal signal.

Harmonics can be classified according to their order or frequency and sequence of phases, as the example of Table V.

TABLE V. HARMONIC ORDER OR FREQUENCY

\begin{tabular}{ccc}
\hline Order & Frequency $(\mathbf{H z})$ & Sequence \\
\hline $1^{\mathrm{a}}$ & 60 & + \\
$3^{\mathrm{a}}$ & 180 & 0 \\
$5^{\mathrm{a}}$ & 300 & - \\
$7^{\mathrm{a}}$ & 420 & + \\
\hline
\end{tabular}

It can be seen in Table $\mathrm{V}$ that the harmonics have positive $(+)$, negative (-) and zero (0) sequence. Equations (7), (8) and (9) monitoring the source of phase sequence. However, by not having characteristic presence in electrical systems, the even order harmonics are not addressed in this paper. Analyzing (7), (8) and (9), it is observed that the phase sequence of harmonics directly depends on its order:

$$
\begin{aligned}
& v_{\text {na }}(\mathrm{t})=\mathrm{V}_{\text {nam }} \sin \mathrm{n}(\omega \mathrm{t}) \\
& v_{\mathrm{nb}}(\mathrm{t})=\mathrm{V}_{\mathrm{nbm}} \sin \mathrm{n}\left(\omega \mathrm{t}-120^{\circ}\right) \\
& v_{\mathrm{nc}}(\mathrm{t})=\mathrm{V}_{\mathrm{ncm}} \sin \mathrm{n}\left(\omega \mathrm{t}+120^{\circ}\right)
\end{aligned}
$$

Where $\mathrm{n}$ is the harmonic order, vna(t), vnb(t),vnc(t) and Vnam, Vnbm, Vncm represent, respectively, the instantaneous values of the voltages and maximum values of the fundamental and harmonic voltages in phases $\mathrm{A}, \mathrm{B}$ and $\mathrm{C}$.

Equations (10) through (15) describe the mathematical model to the fundamental frequency voltages, and Figure 5 illustrates, on the trigonometric circle, the phase sequence to the same.

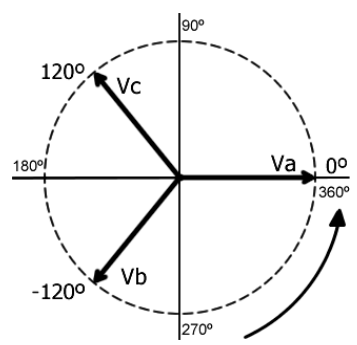

$$
\begin{aligned}
& v_{1 \mathrm{a}}(\mathrm{t})=\mathrm{V}_{1 \mathrm{am}} \sin 1(\omega \mathrm{t}) \\
& v_{1 \mathrm{a}}(\mathrm{t})=\mathrm{V}_{1 \mathrm{am}} \sin (\omega \mathrm{t}) \\
& v_{1 \mathrm{~b}}(\mathrm{t})=\mathrm{V}_{1 \mathrm{bm}} \sin 1\left(\omega \mathrm{t}-120^{\circ}\right) \\
& v_{1 \mathrm{~b}}(\mathrm{t})=\mathrm{V}_{1 \mathrm{bm}} \sin \left(\omega \mathrm{t}-120^{\circ}\right) \\
& v_{1 \mathrm{c}}(\mathrm{t})=\mathrm{V}_{1 \mathrm{~cm}} \sin 1\left(\omega \mathrm{t}+120^{\circ}\right) \\
& v_{1 \mathrm{c}}(\mathrm{t})=\mathrm{V}_{1 \mathrm{~cm}} \sin \left(\omega \mathrm{t}+120^{\circ}\right)
\end{aligned}
$$

Fig. 5. Diagram of the fundamental voltages and its direction of rotation.

In the case of the third harmonic (16) to (23) illustrate the mathematical development to voltage while Figure 6 shows the performance on trigonometric circle.

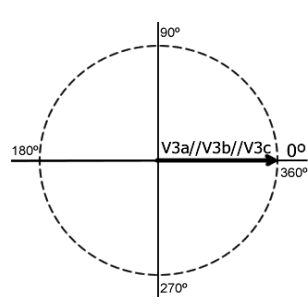

$$
\begin{aligned}
& v_{3 \mathrm{a}}(\mathrm{t})=\mathrm{V}_{3 \mathrm{am}} \sin 3(\omega \mathrm{t}) \\
& v_{3 \mathrm{a}}(\mathrm{t})=\mathrm{V}_{3 \mathrm{am}} \sin (3 \omega \mathrm{t}) \\
& v_{3 \mathrm{~b}}(\mathrm{t})=\mathrm{V}_{3 \mathrm{bm}} \sin 3\left(\omega \mathrm{t}-120^{\circ}\right) \\
& v_{3 \mathrm{~b}}(\mathrm{t})=\mathrm{V}_{3 \mathrm{bm}} \sin \left(3 \omega \mathrm{t}-360^{\circ}\right) \\
& v_{3 \mathrm{~b}}(\mathrm{t})=\mathrm{V}_{3 \mathrm{bm}} \sin (3 \omega \mathrm{t}) \\
& v_{3 \mathrm{c}}(\mathrm{t})=\mathrm{V}_{3 \mathrm{~cm}} \sin 3(\omega \mathrm{t}+120) \\
& v_{3 \mathrm{c}}(\mathrm{t})=\mathrm{V}_{3 \mathrm{~cm}} \sin \left(3 \omega \mathrm{t}+360^{\circ}\right) \\
& v_{3 \mathrm{c}}(\mathrm{t})=\mathrm{V}_{3 \mathrm{~cm}} \sin (3 \omega \mathrm{t})
\end{aligned}
$$

Fig. 6. Diagram of zero sequence harmonic voltages.

The expressions (16) to (23) indicate that, for the case of the third order, the three voltages are in phase, being known as zero sequence harmonic voltages.

Equations (24) to (33) show the mathematical development for the 5th harmonic, and Figure 7 illustrates the behavior for the sequence of phases thereof.

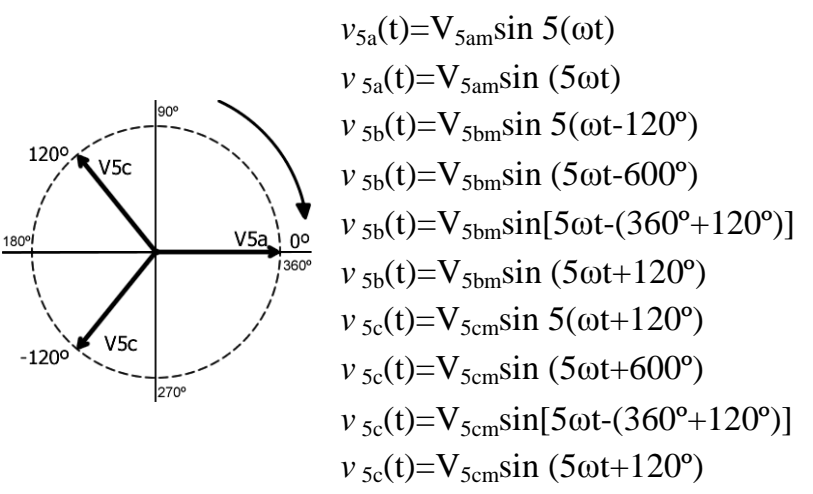

Fig. 7. Diagram of negative sequence voltage harmonics and their direction of rotation.

In the case of the fifth harmonic, as illustrated in Figure 7 , one can observe that the three voltages are $120^{\circ}$ out of phase and direction of rotation of the phasors is contrary to the fundamental, thus known as harmonic voltages of negative sequence.

Finally, (34) to (43) shows the mathematical development to the 7 th harmonic, and Figure 8 shows the behavior in the trigonometric circle. 


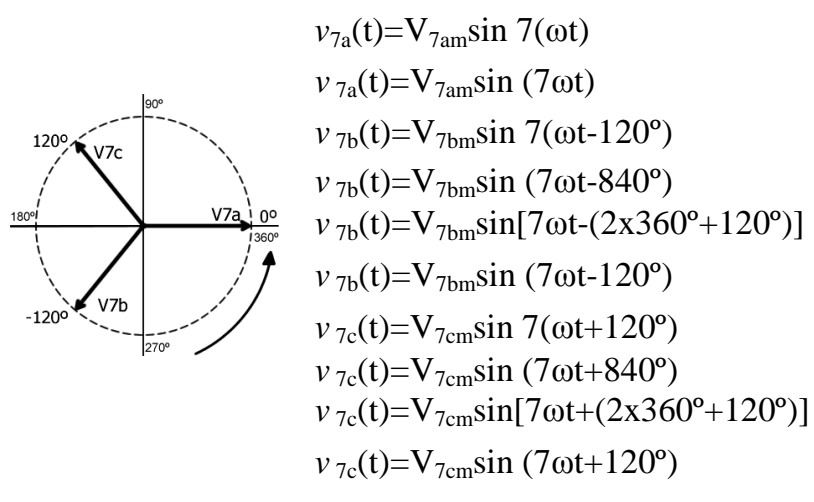

Fig. 8. Diagram of positive sequence harmonic voltages and their direction of rotation.

As in the previous case, it can be seen that the three voltages are $120^{\circ}$ out of phase, however, in this case the direction of rotation coincides with the fundamental voltage, i.e. the direction of rotation counterclockwise, known as harmonic components positive voltage phase sequence.

The mathematical proofs of other harmonics, i.e., 9 th, 11 th, 13 th, 15 th, 17 th, 19 th, 21 th, 23 th and 25 th are analogous to the previous ones, since they alternate the sequences zero, negative and positive.

\section{B. Currents measures in incandescent and fluorescent bulbs.}

To analyze the impact of replacing incandescent light bulbs by fluorescent in power quality tests and comparisons were performed in the laboratory with the two types of technology. Initially were monitored in laboratory electrical currents required by bus phase fluorescent lamps with electronic ballast with the aim of verifying the quality of electricity. The lamps used in the test were the same used in the replacement process on this energy efficiency project. Figure 9 depicts the scheme used to check experimental measurement of the characteristics of the electrical current requested bus by this new technology.

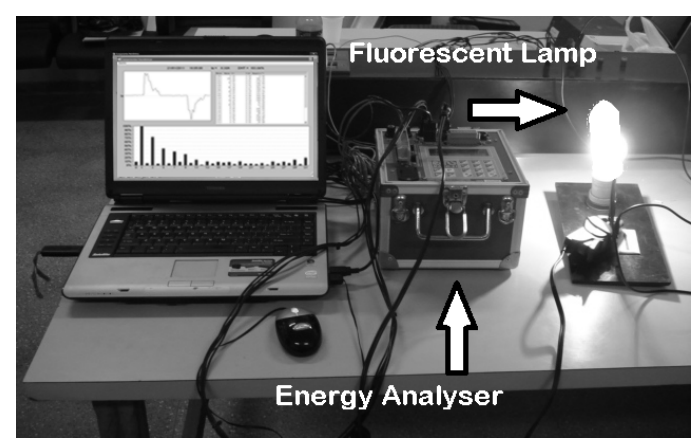

Fig. 8. Scheme measuring Fluorescent Lamp.

After the measurements of fluorescent lights, broke for the second part which was monitoring the incandescent bulb. The measurement scheme is shown in Figure 10. Incandescent lamps used for the tests, the same substituted by this energy efficiency project, had nominal power of 100W.

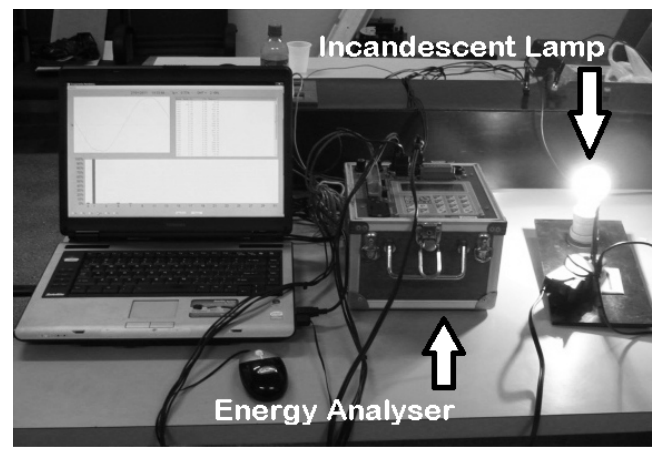

Fig.10 Measurement Scheme Incandescent Lamps.

Thus, for a simplified analysis, we compared the results obtained with the fluorescent lamp of incandescent lamp, whose waveforms are shown in Figures 11 and 12. .

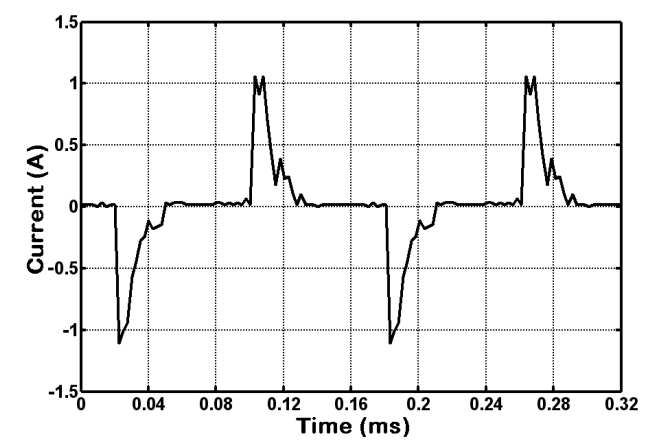

Fig. 11. Current Waveform required by a compact fluorescent lamp 20W.

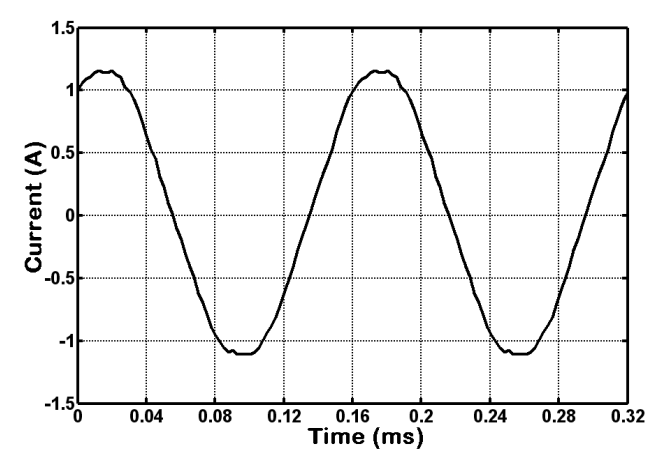

Fig. 12. Current Waveform requested by an incandescent lamp $20 \mathrm{~W}$.

By inspection of Figures 11 and 12, it is clear that the current signal applied by the bus fluorescent lamp has a high harmonic distortion relative to the current signal of the incandescent lamp, which can be best observed in the spectra illustrated in Figure harmonics 13.

The graph shown in figure 13, shows that the difference between the characteristic fluorescent lamps used in the assay relative to incandescent, when it comes to quality of electrical energy, is considerably high because the fluorescent lamp pumped large amounts of harmonic distortion in system, causing the current waveform lost its characteristic having a sinusoidal current value of DHT around $110.43 \%$ as shown in Table VI. 


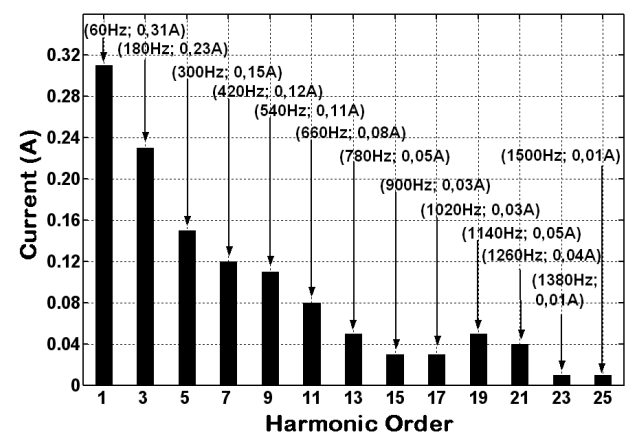

Fig. 13. Harmonic spectrum of current required by the fluorescent lamp.

TABLE VI. INDIVIDUAL AND TOTAL HARMONIC DISTORTION CURRENT

\begin{tabular}{ccc}
\hline $\begin{array}{c}\text { Harmonic } \\
\text { Order }\end{array}$ & \multicolumn{2}{c}{ Harmonic Distortion } \\
DHIi (\%) & DHTi (\%) \\
\hline $3^{\mathrm{a}}$ & 76,01 & \\
$5^{\mathrm{a}}$ & 47,54 & \\
$7^{\mathrm{a}}$ & 37,93 & \\
$9^{\mathrm{a}}$ & 36,56 & 110,43 \\
$11^{\mathrm{a}}$ & 26,83 & \\
$13^{\mathrm{a}}$ & 16,56 & \\
$15^{\mathrm{a}}$ & 8,57 & \\
$17^{\mathrm{a}}$ & 10,92 & \\
$19^{\mathrm{a}}$ & 15,16 \\
$21^{\mathrm{a}}$ & 13,15 & \\
$23^{\mathrm{a}}$ & 4,50 & \\
$25^{\mathrm{a}}$ & 5,59 & \\
\hline
\end{tabular}

\section{CONCLUSION}

The cost of electricity is today, for all consumers, a remarkable factor in your monthly expenses to carry out its activities. Thus, a reduction in the value of the active power bill represents a financial gain for these consumers, improving their quality of life with regard to citizenship and social inclusion. With regard to the concessionaire, there is a possibility of serving new loads without the need for investments to expand its distribution system. What, indeed, is the main benefit acquired by the concessionaire in this type of project.

Given the above, it can be said that joint action between concessionaire and consumers are currently the main foundation for the development of methodologies that allow a reduction in financial, technical, commercial and social losses, imposed to distributors and users, caused by the irrational use of resources available and electrical appliances not with PROCEL stamp.

Before and after the implementation of energy efficiency project, i.e. the replacement of incandescent bulbs and conventional refrigerators, fluorescent compact bulbs and refrigerators with PROCEL stamp in Consumer Units covered in this study, field measurements were conducted on a sample of lamps and coolers, based on a sampling plan defined by
NBR 5426 inspection regime with level I. The results achieved through the campaigns of field measurements show that, with respect to active power consumption and demand of active power, the gains were quite significant with the implementation of the Energy Efficiency Project.

As for power quality, the results obtained from experimental tests carried out in laboratories on several lamps LFCs, show a high harmonic spectrum for currents required by this new technology. The effects of current distortion, besides adversely affect the values of the electrical and the consequent burden on drivers and equipment, may also affect the proper operation of protective devices, which can act due to increments of peak or rms values of these quantities. From the foregoing, it is understood that should be adopted mitigation techniques for this type of disturbance. One of the most common methods of solving the problem is to use harmonic filters, which can be installed next to the "source" pollutants (or inside them). Since knowledge of these disturbances present in electrical systems requires special attention and should be taken preventive measures, thereby ensuring safe projects, avoiding risk situations for users and equipment.

\section{REFERENCES}

[1] APOLÔNIO, Roberto ; KAWAPHARA, Mario Kiyoshi. ; VASCONCELLOS, Arnulfo Barroso . Eficiência Energética Versus Qualidade da Energia Elétrica : Um Estudo de Caso em Prédios Públicos. In: XVII Seminário Nacional de Distribuição de Energia Elétrica, 2006, Belo Horizonte - MG. XVII Seminário Nacional de Distribuição de Energia Elétrica, 2006.

[2] ASSOCIAÇÃO BRASILEIRA DE NORMAS TÉCNICAS. Planos de amostragem e procedimentos na inspeção por atributos - NBR 5426. Rio de Janeiro, Jan. / 1985. Versão Corrigida 1989.

[3] ELETROBRÁS/PROCEL EDUCAÇÃO (2006). Eficiência Energética de Equipamentos e Instalações. Itajubá Janeiro: LTC/Eletrobrás/ EFEI.

[4] GOMES, Teresa Irene Ribeiro Carvalho Malheiro ; VASCONCELLOS, Arnulfo Barroso ; OCHIUTO, M. S. ; BARROS, R. S. ; BERNARDES, T. A. . Avaliação técnica da redução do consumo de energia elétrica e demanda de potência ativa no campus da UFMT após a implantação do projeto de eficiência energética. In: VI CBPE - Congresso Brasileiro de Planejamento Energético, 2008, Salvador. VI CBPE - Congresso Brasileiro de Planejamento Energético - Energia e Meio Ambiente, 2008.

[5] LUCIANO, B. A. (1986). Medição de energia elétrica (Normas para instalações de cabines de medição). Campina Grande: Depto. De Engenharia Elétrica/CCT/UFPB.

[6] SILVA, WILTON P. E SILVA, CLEIDE M. D. P. S (1998). Tratamento de dados experimentais. João Pessoa - Editora Universitária da UFPBAtlas de energia elétrica do Brasil. Agência Nacional de Energia Elétrica. Ed. Brasília: Aneel, 2008.

[7] VASCONCELLOS, Arnulfo Barroso ; B. C. Carvalho ; APOLÔNIO, Roberto ; MARTINS, D. L. R. ; T.V. da Silva ; GOMES, Teresa Irene Ribeiro de Carvalho Malheiro ; ANNUNCIACAO, L. . Eficiência Energética em uma Industria de Calcário. In: 3 Congresso Brasileiro de Eficiência Energética, 2009, Belém/PA. 3 CBEE, 2009.

[8] VASCONCELLOS, Arnulfo Barroso ; LAMBERT, José Antônio ; NOGUEIRA, M. C. J. A. ; B. C. Carvalho ; SILVA, A. C. J. ; ANNUNCIACAO, L. . Análise da Iluminância com Lâmpadas Fluorescentes Quanto ao Nível de Tensão no Reator. In: 3 Congresso Brasileiro de Eficiência Energética, 2009, Belém/PA. 3 CBEE, 2009.

[9] VASCONCELlOS, Arnulfo Barroso ; BARROS, R. S. ; BERNARDES, T. A. ; GOMES, Teresa Irene Ribeiro de Carvalho Malheiros ; B. C. Carvalho ; ANNUNCIACAO, L. . Avaliação de Resultados após Implantação de um Projeto de Eficiência Energética na UFMT. In: 3 Congresso Brasileiro de Eficiência Energética, 2009, Belém/PA. 3 CBEE, 2009. 